\title{
Treatment of dairy wastewater in UASB-UF system
}

\author{
Anna Kwarciak-Kozłowska ${ }^{1, *}$, and January Bień $^{1}$ \\ ${ }^{1}$ Czestochowa University of Technology, Institute of Environmental Engineering, Dabrowskiego 69, \\ 42-200 Czestochowa, Poland
}

\begin{abstract}
The examinations concerned determination of the treatment efficiency of wastewater form dairy industry using the system which combines methane fermentation with ultrafiltration process. The study attempted to determine the effect of HRT and OLR on the degree of biodegradation of contaminants contained in the sludge examined and on the quality and amount of biogas. The anaerobic process obtained a considerable degree of the removal of organic pollutants from raw wastewater designated as COD $(73.8 \%)$, BOD $(81.2 \%)$ and TOC $(76 \%)$. The concentrations of COD and BOD were $1053 \mathrm{mg} / \mathrm{dm}^{3}$ and $329 \mathrm{mg} / \mathrm{dm}^{3}$, respectively. The value of TOC reached a level of $288 \mathrm{mg} / \mathrm{dm}^{3}$. Generated biogas in the methane fermentation process of wastewater from dairy wastewater was characterized by high methane content ( $82 \%$ vol.). In the final part of the experiment, the UF process was used in order to posttreating effluent from UASB reactor. During the UF process, COD, BOD and TOC parameters were removed at $72 \%, 63 \%$ and $67 \%$, respectively.
\end{abstract}

\section{Introduction}

Dairy processing belongs to major directions of agricultural production in Europe. Due to beneficial natural conditions and long tradition of breeding and rearing of cattle, Poland is numbered among top producers of milk and dairy products. It is estimated that nearly 12 billion of cubic metres of milk is produced in the country every year. Polish dairy industry is currently fourteenth in the world and fourth in the European Union in terms of milk production $[1,2]$. Two types of wastewater are generated in dairy factories: industrial and non-industrial wastewater. Industrial wastewater is generated during cleaning the floors and equipment, but it also comes from leakages and milk loss. In some dairy factories, whey is also discharged to the industrial wastewater, substantially increasing the load of contaminants. The non-industrial wastewater (e.g. sanitary wastewater, post-cooling wastewater and stormwater) represents a substantial part of total volume of the wastewater, but it is characterized by a low content of organic matter [1-3].

The amount of industrial wastewater depends on the size of the factory and type of production. A typical Polish dairy plant discharges $450-600 \mathrm{~m}^{3} / \mathrm{d}$ of wastewater, containing on average $200-700 \mathrm{mg} / \mathrm{dm}^{3}$ BOD (max. 3000-5000 mg/dm ${ }^{3}$ ). In general, chemical oxygen

\footnotetext{
* Corresponding author: akwarciak@is.pcz.czest.pl
} 
demand (COD) in dairy wastewater ranges from 1150 to $9200 \mathrm{mg} / \mathrm{dm}^{3}$ [1-5]. Dairy wastewater contains dissolved and crystallized fat, carbohydrates (lactose) and protein in its colloidal form and nitrogen and phosphorous compounds e.g. from the washing processes. The quality of wastewater generated in a dairy is determined by the type of production, content of raw material and technological advances of the plant [4-6]. Dairy wastewater temperature is usually $20-30^{\circ} \mathrm{C}$ and is characterized by weak alkaline reaction $(\mathrm{pH} 7-8.8)$. It is easily putrefied due to lactose fermentation. Wastewater with these properties can be successfully treated using biological processes (aerobic and/or anaerobic). In most cases, modern methods of biological treatment of wastewater in anaerobic conditions meet European requirements concerning treatment of industrial wastewater. Anaerobic methods were used for many years only for stabilization of sewage sludge and it was in the beginning of the $70 \mathrm{~s}$ of the last century when the interest in these processes as effective technologies of industrial wastewater treatment started to be more pronounced [7-9]. Dairy wastewater having a high fat content has the highest methane potential among several types of food wastewater.

During treatment of wastewater in aerobic conditions, $50 \%$ of organic compounds expressed as COD is transformed into the sludge, whereas other $50 \%$ is converted into heat energy that in practice remains unused. During the anaerobic treatment, only $10 \%$ of organic compounds are used to obtain biomass, with $80 \%$ turned into methane that can be used for energy purposes. During methane fermentation, around 3 to 20 times more excess sludge is generated compared to aerobic processes, which is connected with low rate of increase of aerobic bacteria. In the case of anaerobic treatment, nearly $1 \mathrm{~kg}$ of removed COD generates the energy of $3.4 \mathrm{kWh}$ and it is estimated that $1 \mathrm{~kg}$ of decomposed organic matter can be used to obtain $0.35 \mathrm{~m}^{3}$ methane [6-9]. The benefit of methane fermentation is the ability to decompose fats and suspensions contained in the wastewater. Therefore, there is no necessity to build additional installations for removing these contaminants using physical and chemical methods [9]. Technologically, treatment of wastewater from food processing industry is based on the use of UASB bioreactors, designed by Letting and his colleagues in the seventies of the last century in the Netherlands. Biomass used in this bioreactor occurs in the form of granulated sludge, which is characterized by very good sedimentation properties, resistance to fluctuation in the load of contaminants in the wastewater supplied to the bioreactor and low unit increase in the sludge (from 0.11 to $0.22 \mathrm{~kg}_{\text {v.s.s }} / \mathrm{kgCOD}_{\text {rem. }}$ ) [7-9].

The example of the use of this type of reactors for treatment of industrial dairy wastewater is a Finnish dairy which manufacturers $165000 \mathrm{~m}^{3}$ of wastewater per year. Reduction in COD ranges from $70 \%$ to $90 \%$, whereas daily biogas production with $70 \%$ of methane content is $400 \mathrm{~m}^{3}$. Another example is a dairy plant in the UK, where, after installation of an UASB reactor to treat whey and wastewater from the cream production is obtained such biogas amounts of biogas which allow for covering of the total energy demand in the plant $[10,11]$.

\section{Material and methods}

\subsection{Substrate}

The study examined industrial wastewater from one of the biggest dairy factories located in the Świętokrzyskie Voivodeship in Poland. The factory processes $400 \mathrm{~m}^{3}$ of milk per day. The factory is equipped with its own wastewater treatment plant with capacity of up to $800 \mathrm{~m}^{3} / \mathrm{d}$. The average characteristics of dairy wastewater are shown in Table 1 . 
Table 1. Average characteristics of dairy wastewater.

\begin{tabular}{|c|c|c|c|}
\hline Parameter & Unit & Raw wastewater & $\begin{array}{c}\text { Permissible standards for natural } \\
\text { receiver [12] }\end{array}$ \\
\hline $\mathrm{pH}$ & - & 8.2 & $6.5-9.0$ \\
\hline $\mathrm{COD}$ & $\mathrm{mg} / \mathrm{dm}^{3}$ & 4020 & 125 \\
\hline $\mathrm{BOD}$ & $\mathrm{mg} / \mathrm{dm}^{3}$ & 1750 & 25 \\
\hline TOC & $\mathrm{mg} / \mathrm{dm}^{3}$ & 1200 & 30 \\
\hline Total nitrogen & $\mathrm{mg} / \mathrm{dm}^{3}$ & 290 & 15 \\
\hline
\end{tabular}

\subsection{Apparatus}

The UASB reactor with the volume of $5 \mathrm{dm}^{3}$ was made of the organic glass (PMMA). Constant temperature of the anaerobic fermentation $\left(36 \pm 2{ }^{\circ} \mathrm{C}\right)$ was maintained by means of ultrathermostat that pumped the heated water to the heating jacket of the bioreactor. The UASB effluent was collected in the upper part of a reaction chamber, whereas the generated gas was collected in a calibrated container. The examinations used granulated sludge collected from the anaerobic IC bioreactor used in the wastewater treatment plant in Żywiec S.A. Brewery. The sludge was in the form of granules with the diameter of 3 to $5 \mathrm{~mm}$ and dry mass of $78.35 \mathrm{~g} / \mathrm{dm}^{3}$ (including the content of organic matter of $62.15 \mathrm{~g} / \mathrm{dm}^{3}$ and mineral substances of $\left.16.20 \mathrm{~g} / \mathrm{dm}^{3}\right)$.

Ultrafiltration posttreatment of the dairy wastewater was conducted using the research stand Millipore CDS-10. The system was operated in the dead-end one-directional arrangement at the pressure of $0.1 \mathrm{MPa}$. The membrane installation was composed of the ultrafiltration cell containing a flat membrane with an active surface of $0.045 \mathrm{~m}^{2}$. The cell was connected through a reducer with a gas cylinder (with oxygen). The reducer allowed for adjustment of gas pressure in the range of 0.1 to $0.25 \mathrm{MPa}$. The study used hydrophilic ultrafiltration membrane made of polyethersulfone (PES) with cut-off of $50 \mathrm{kDa}$ [13].

\subsection{Research methodology}

The examinations were divided into two stages. In the first stage, dairy wastewater was initially treated biologically using a methane fermentation process. This operation was performed in an UASB bioreactor to which granulated anaerobic sludge with concentration of $10 \mathrm{~g} / \mathrm{dm}^{3}$ was supplied. Four series of examinations were performed, with hydraulic retention time ranging from $4 \mathrm{~d}$ to $1.5 \mathrm{~d}$. Duration of this stage was 80 days. After initial biological treatment of dairy products, the effluent from the UASB reactor was supplied to the ultrafiltration membrane module in order to ensure final treatment (Stage 2). At this stage, the transport and separation properties of the membranę were determined $[14,15]$. The study design and methodology of determination is presented in Fig. 1.

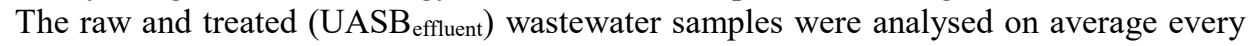
two days in terms of changes in COD, TOC, $\mathrm{pH}$, alkalinity and volatile fatty acids (VFA). Measurements of BOD and TN were performed once a week. The composition and amount of the biogas generated in the process was monitored continuously. The permeate after the ultrafiltration process was analysed in terms of changes in BOD, COD, TOC and TN. The HACH DR/4000 spectrophotometer was used to perform the measurements of chemical oxygen demand (COD). BOD was determined using the respirometric method by means of the measurement set OXI Top WTW. Kiper TOC 10C Analyser PX-120 with AS40Dione3.11 autosampler was used for the determination of total organic carbon (TOC) and total nitrogen $(\mathrm{TN})$. CP-401/CP-40 $\mathrm{pH}$-meter was used to measure $\mathrm{pH}$ during the process of 
anaerobic biodegradation of dairy wastewater. The amount of volatile fatty acids was determined according to PN-75/C-04616/04, whereas alkalinity was determined based on PN90/C-04540/03. The composition of the biogas generated was analysed by means of the SR2-DO (Germany) biogas analyser.

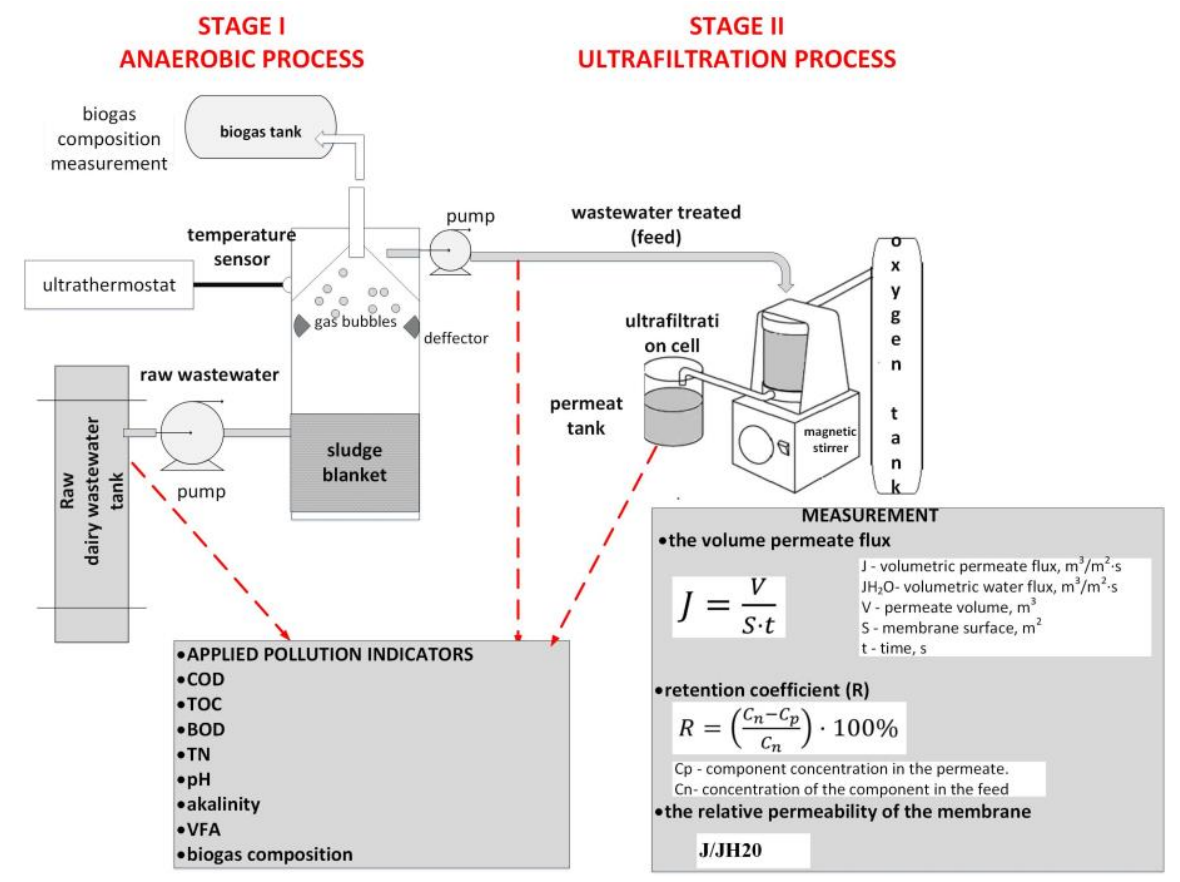

Fig. 1. The scheme of dairy wastewater treatment in the UASB-UF system.

\section{Results and discussion}

\subsection{Anaerobic treatment of dairy wastewater}

Hydraulic retention time for dairy wastewater in the reaction chamber was changed from $4 \mathrm{~d}$ to $1.5 \mathrm{~d}$, which resulted in the change of organic loading rate (OLR) from $1 \mathrm{~kg} \mathrm{COD} / \mathrm{m}^{3} \mathrm{~d}$ to $2.6 \mathrm{~kg} \mathrm{COD} / \mathrm{m}^{3} \mathrm{~d}$, respectively. Time of dairy wastewater fermentation process at specific hydraulic retention times (HRT) and OLR levels during the entire experiment are presented in Fig. 2a. During treatment of wastewater using the longest HRT time of $4 \mathrm{~d}\left(1^{\text {st }}\right.$ to $26^{\text {th }}$ day of the experiment) mean degree of removal of COD, TOC and BOD was $60 \%, 64 \%$ and $71 \%$, respectively. Value of COD, TOC and BOD for treated wastewater amounted in this case to $1608 \mathrm{mg} / \mathrm{dm}^{3}, 432 \mathrm{mg} / \mathrm{dm}^{3}$ and $525 \mathrm{mg} / \mathrm{dm}^{3}$, respectively. Shortening of HRT from $4 \mathrm{~d}$ to $3 \mathrm{~d}\left(27^{\text {th }}\right.$ to $46^{\text {th }}$ day) contributed to the increase in the load of the chamber with the contaminant load from $1 \mathrm{~kg} \mathrm{COD} / \mathrm{m}^{3} \mathrm{~d}$ to $1.34 \mathrm{~kg} \mathrm{COD} / \mathrm{m}^{3} \mathrm{~d}$ and to the increase in the degree of COD removal by $6 \%$ and TOC and BOD by $5 \%$. Shortening of HRT time to $2 \mathrm{~d}$ led to the rise in the organic loading rate to $2 \mathrm{~kg} \mathrm{COD} / \mathrm{m}^{3} \mathrm{~d}\left(47^{\text {th }}\right.$ to $68^{\text {th }}$ day). The wastewater treated during this retention time was characterized by lower content of COD $\left(1053 \mathrm{mg} / \mathrm{dm}^{3}\right)$, TOC $\left(288 \mathrm{mg} / \mathrm{dm}^{3}\right)$ and BOD $\left(329 \mathrm{mg} / \mathrm{dm}^{3}\right)$. During wastewater treatment using the shortest of the examined retention times (HRT of $1.5 \mathrm{~d}$ ), a substantial deterioration was observed for the quality of wastewater 
treated, with the values of COD, TOC and BOD of $1527 \mathrm{mg} / \mathrm{dm}^{3}, 420 \mathrm{mg} / \mathrm{dm}^{3}$ and $455 \mathrm{mg} / \mathrm{dm}^{3}$, respectively. Changes of COD and TOC treated during the experiment were presented in Fig. $2 \mathrm{~b}$ and 2c, whereas BOD values are shown in Fig. 3a.

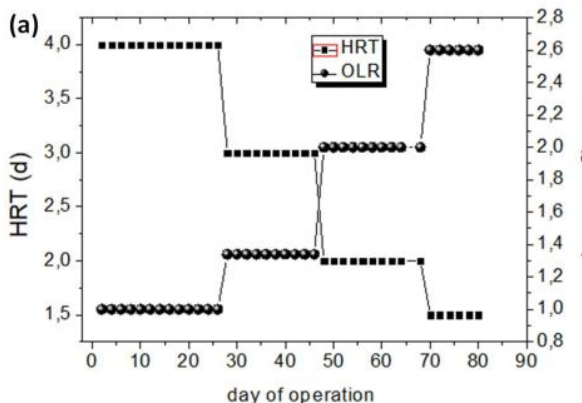

(b)

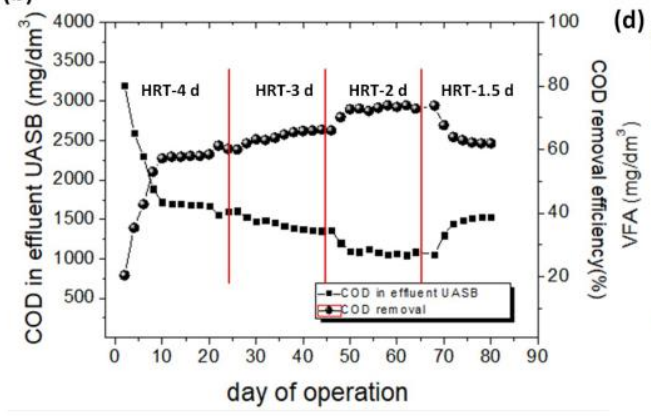

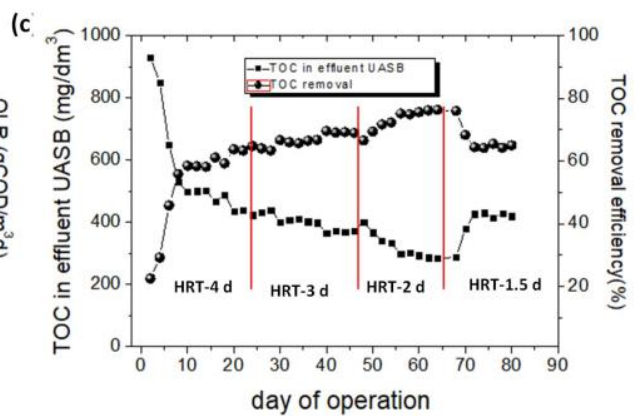

(d)

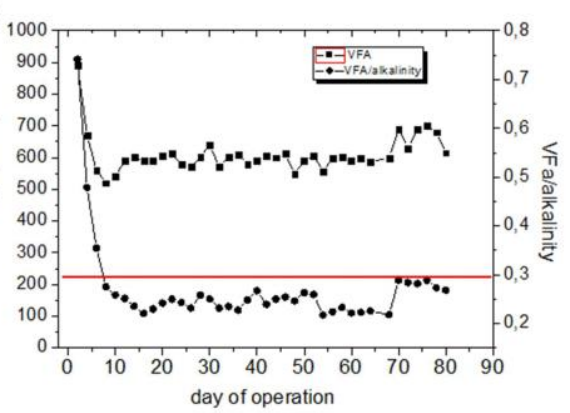

Fig. 2. The impact of HRT on the value of OLR (a), COD (b), TOC (c) and VFA/alkalinity (d) in dairy wastewater treatment.

The results are similar to those obtained by previous researchers during anaerobic treatment of this type of industrial wastewater. In a study by Latif et al., the COD removal rate ranged from $64 \%\left(\mathrm{HRT}=1.5 \mathrm{~d}\right.$ and $\left.\mathrm{OLR}=0.24 \mathrm{~kg} \mathrm{COD} / \mathrm{m}^{3} \mathrm{~d}\right)$ to $98 \%(\mathrm{HRT}=6 \mathrm{~d}$ and OLR $=6.2 \mathrm{~kg} \mathrm{COD} / \mathrm{m}^{3} \mathrm{~d}$ ). Tawfik et al., demonstrated that during the UASB reactor operation for HRT 1d and OLR of $1.9 \mathrm{~kg} \mathrm{COD} / \mathrm{m}^{3} \mathrm{~d}$, the efficiency of COD removal was $69 \%$ [16-18].

VFA and alkalinity together are the good indicators for evaluating the process stability of the anaerobic reactor since total alkalinity reflects both levels of VFA and bicarbonates, and under unstable conditions increased VFA reduce bicarbonates resulting in constant total alkalinity [19]. With undisturbed course of the process, the ratio of alkalinity to VFA should not exceed 0.3 [20] whereas inhibition of the development of methanogens in the reaction chamber occurs when its value exceeds 0.8 [21]. In the first days of the experiment, the VFA/alkalinity ratio was very high: 0.7 ( $2^{\text {nd }}$ day) and 0.36 ( $6^{\text {th }}$ day). From the 7 th day, the value of the ratio was below 0.3 and ranged from 0.21 and 0.29 . It was also observed that during the process performed at HRT of 1.5 days, the index adopted higher values, ranging from 0.28 to 0.29 . (Fig. 2d). Comparison of the quality of treated wastewater depending on hydraulic retention time in the bioreator was presented in Fig. $3 \mathrm{~b}$. Volume and composition of the released gas were also evaluated during the fermentation process. Biogas yield $(Y)$ was also computed from the following formula:

$$
Y=\frac{V_{b}}{a}, \mathrm{dm}^{3} / \mathrm{gCOD}_{\mathrm{rem}} .
$$


where:

$V_{b}$ - volume of biogas generated during the day, $\left(\mathrm{dm}^{3} / \mathrm{d}\right)$,

$a$ - the amount of removed COD during the day, $(\mathrm{g} / \mathrm{d})$.
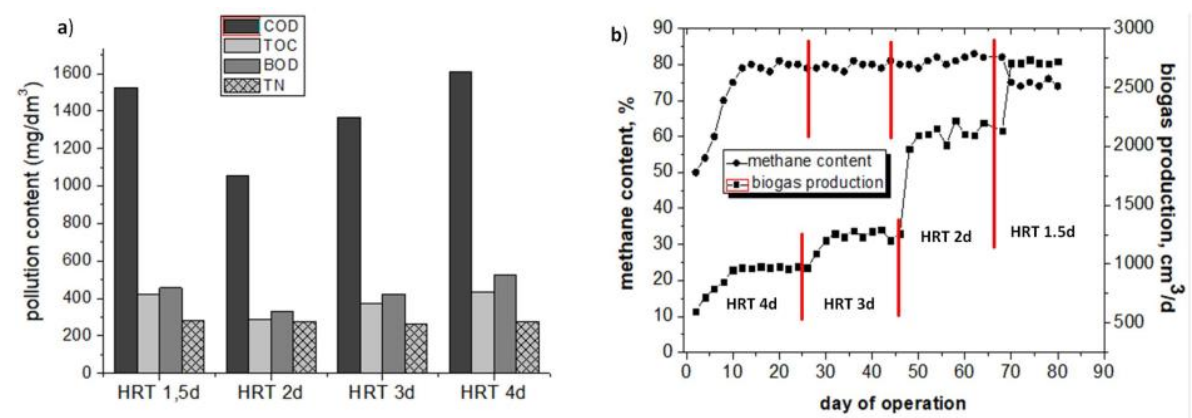

Fig. 3. The impact of HRT on the value of pollution content (a) and biogas production/methane content (b) in dairy wastewater treatment.

During fermentation at HRT $1.5 \mathrm{~d}$, daily biogas yield was the highest $\left(2704 \mathrm{~cm}^{3}\right)$. The use of longer hydraulic retention time was related with lower daily biogas yield. Daily biogas yield at HRT $2 \mathrm{~d}$ and HRT $3 \mathrm{~d}$ was lower than that obtained at HRT $1.5 \mathrm{~d}$ by $23 \%$ $\left(2100 \mathrm{~cm}^{3}\right)$ and $46 \%\left(1260 \mathrm{~cm}^{3}\right)$.

A very important parameter monitored during anaerobic treatment of dairy wastewater was biogas yield efficiency. With longer HRT of $3 \mathrm{~d}$ and $4 \mathrm{~d}$, biogas yield efficiency was at a similar level of ca. $0.43 \mathrm{dm}^{3}$ biogas $/ \mathrm{g} \mathrm{COD}_{\text {rem. }}$.). At HRT $2 \mathrm{~d}$ and HRT $1.5 \mathrm{~d}$ biogas yield efficiency was $0.44 \mathrm{dm}^{3}$ biogas $/ g$ COD rem. and $0.42 \mathrm{dm}^{3}$ biogas $/ g \mathrm{COD}_{\text {rem. }}$. In the first days of the process, percentage of methane in the biogas generated ranged from $50 \%$ to $62 \%\left(2^{\text {nd }}\right.$ to $6^{\text {th }}$ day). It was also found that at HRT $=1.5 \mathrm{~d}$, biogas was characterized by the lowest methane content (74\%). With longer hydraulic retention times (HRT $=3 \mathrm{~d}$ and HRT $=4 \mathrm{~d}$ ), methane percentage was the highest and ranged from $80 \%$ to $82 \%$. Carbon dioxide content in the analyzed biogas samples ranged depending on HRT from $12.5 \%$ to $15.9 \%$. Mean content of $\mathrm{H}_{2} \mathrm{~S}$ and $\mathrm{CO}$ during the entire experiment was 84 and $57 \mathrm{ppm}$, respectively.

\subsection{Post-treatment diary wastewater using the ultrafiltration process}

Before the process of final treatment of the eluate from the UASB reactor in the process of ultrafiltration, transport properties of the membrane used were determined. This consisted in transport of deionized water through a membrane while using the transmembrane pressure ranging from 0.1 to $0.25 \mathrm{MPa}$. The volumetric water flux was determined for each pressure. It was observed that the flux of permeate increased with the increase in pressure used. This relationship was of linear function character. For the highest pressure used, i.e. $0.25 \mathrm{MPa}$, the ultrafiltration membrane was characterized by nearly 3 times higher $\left(23.7 \times 10^{-5} \mathrm{~m}^{3} / \mathrm{m}^{2} \times \mathrm{s}\right)$ volumetric water stream compared with the smallest pressure $\left(0.1 \mathrm{MPa}-8.45 \times 10^{-5} \mathrm{~m}^{3} / \mathrm{m}^{2} \times \mathrm{s}\right)$. After determination of the transport properties of the membrane, filtration of the wastewater initially treated in the methane fermentation process was started. This process was conducted at the pressure of $0.1 \mathrm{MPa}$.

It was found that with the time of the ultrafiltration process, membrane capacity was gradually decreasing. The cause of this phenomenon was the deposition of contaminants in the membrane pores and formation of the filtration cake, which resulted in blocking the pores and a decline in the flux of permeate. After 5 minutes of the process, the permeate 
flux was by $10 \%$ lower compared to the flux of deionized water. After ca. 20 minutes, the permeate flux became steady at the level of $4.92 \times 10^{-5} \mathrm{~m}^{3} / \mathrm{m}^{2} \times \mathrm{s}$. Volumetric changes in the permeate flux depending on the ultrafiltration process are illustrated in Fig. 4a.

Based on the value of initial volumetric water flux and mean value of volumetric permeate flux, the relative membrane permeability after 60 minutes of the ultrafiltration final treatment was determined (0.68). As expected, the ultrafiltration process ensured a high degree of removal of the contaminants from the initially biologically treated wastewater. The degree of removal of COD, TOC and BOD and TN reached the levels of $72 \%\left(295 \mathrm{mg} / \mathrm{dm}^{3}\right), 67 \%\left(108 \mathrm{mg} / \mathrm{dm}^{3}\right), 69 \%\left(89 \mathrm{mg} / \mathrm{dm}^{3}\right)$ and $43 \%\left(176 \mathrm{mg} / \mathrm{dm}^{3}\right)$, respectively. The results obtained in the study demonstrated that wastewater treated in the system studied were unsuitable for immediate discharge to a natural reservoir. The value of indices for wastewater treated according to the ordinance of the Minister of Environment as of 18 November 2014 was exceeded over three times (TOC and COD), or four times (BOD) and twelve times (TN) [12]. It is planned in the future to replace the process of ultrafiltration with reverse osmosis and using a final ammonia stripping step in the technological system.
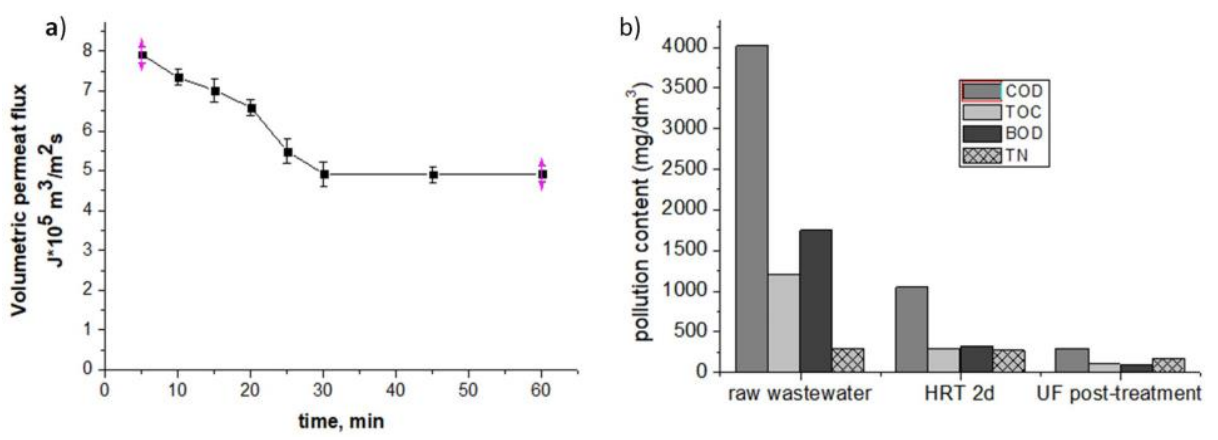

Fig. 4. The changes of the permeate flux (a) and the quality of dairy wastewater purified in the UASB-UF system (b).

\section{Conclusions}

It was found that:

1) methane fermentation was the most efficient at HRT of 2 days, with the content of COD, TOC and BOD in treated wastewater being the lowest, with $1053 \mathrm{mg} / \mathrm{dm}^{3}$, $288 \mathrm{mg} / \mathrm{dm}^{3}$ and $329 \mathrm{mg} / \mathrm{dm}^{3}$, respectively;

2) the biogas generated at the most beneficial conditions of the process of methane fermentation of dairy wastewater was characterized by a high methane content ( $82 \%$ vol.);

3 ) the degree of removal of COD, TOC and total nitrogen after ultrafiltration reached the levels of $72 \%\left(295 \mathrm{mg} / \mathrm{dm}^{3}\right), 67 \%\left(108 \mathrm{mg} / \mathrm{dm}^{3}\right)$ and $43 \%\left(176 \mathrm{mg} / \mathrm{dm}^{3}\right)$, respectively;

4) due to low quality, permeate after the process of ultrafiltration cannot be discharged to a natural reservoir. The ultrafiltration process is planned to be replaced by reverse osmosis. 


\section{References}

1. J. Struk-Sokołowska, Inż. Eko. 24, 130-144 (2011)

2. M. Olszewska, Wiad. Zootech. 3, 150-157 (2015)

3. M. Wojnicz, Mono. PAN KIŚ 59, 2 (2009)

4. B. Demirel, O.Y. Turgut, T. Onay, Proc. Biochem. 40, 8, 583-2595 (2005)

5. W. Dąbrowski, Inż. Eko. 24, 236-242 (2011)

6. J.R. Danalewich, T.G. Papagiannis, R.L. Belyea, M.E. Tumbleson, L. Raskin, Wat. Res. 32, 12, 3555-3568 (1998)

7. M. Jędrzejewska, Eko. Tech. 4, 32, 22-24 (2004)

8. K. Barbuciński, Agro Przem. 3, 44-47 (2009)

9. K. Barbuciński, Agro Przem. 3-4, 65-69 (2010)

10. M. Janosz-Rajczyk, Wyd. PCz. (2008)

11. W. Janczukowicz, M. Jędrzejewska, M. Krzemieniewski, J. Pesta, Przeg. Mlecz. 1, 30-34, (2003)

12. J. Law, No. item 1800 (2014)

13. A. Kwarciak-Kozłowska, A Krzywicka, M Gałwa-Widera, Rocz. Ochr. Środ. 18, 61-73 (2016)

14. I. Kowalska, Środ.-Pom. Tow. Nauk. Ochr. Środ. 10, 593-604 (2008)

15. M. Bodzek, J. Bohdziewicz, K. Konieczny, Wyd. PŚl. (1997)

16. M.A. Latif, R. Ghufran, Z.A. Wahid, A. Ahmad, Water Res. 45, 4683-4699 (2011)

17. A Tawfik, M. Sobhey, M. Badawy, Desalin. 227, 167-177 (2008)

18. C.S. Couras, V.L. Louros, T. Gameiro, N. Alves, A. Silva, M.I. Capela, L.M. Arroja, H. Nadais, Envir. Tech. 36, 17, 2227-2238 (2015)

19. U.S. Hampannavar, C.B. Shivayogimath, Inter. Jour. of. Envir. Scie. 1, 4, 631-639 (2010)

20. J. Bień, K. Wystalska, Wydawnictwo PCz. (2011)

21. H.W. Zhao, T. Viraraghavan, Biores. Tech. 95, 3, 301-307 (2004) 